\title{
MANAGEMENT OF BRACHIAL PLEXUS MISSILE INJURIES
}

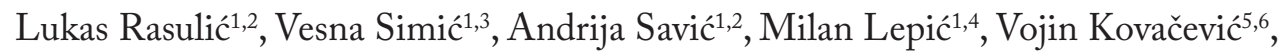 \\ Vladimir Puzović ${ }^{6}$, Filip Vitoševićc ${ }^{1,7}$, Nenad Novaković ${ }^{4}$, Miroslav Samardžić ${ }^{1,2}$ and Krešimir Rotim ${ }^{8,9}$ \\ ${ }^{1}$ Faculty of Medicine, University of Belgrade, Belgrade, Serbia; ${ }^{2}$ Department of Peripheral Nerve Surgery, \\ Functional Neurosurgery and Pain Management Surgery, Clinic for Neurosurgery, Clinical Center of Serbia, \\ Belgrade, Serbia; ${ }^{3}$ Section for Neurosurgery, Department of Surgery, Ćuprija General Hospital, Ćuprija, Serbia; \\ ${ }^{4}$ Department of Neurosurgery, Military Medical Academy, Belgrade, Serbia; ${ }^{5}$ Department of Neurosurgery, \\ Kragujevac Clinical Center, Kragujevac, Serbia; ${ }^{6}$ Faculty of Medical Sciences, University of Kragujevac, \\ Kragujevac, Serbia; ${ }^{7}$ Neuroradiology Department, Center for Radiology and MRI, Clinical Center of Serbia, \\ Belgrade, Serbia; ${ }^{8}$ Department of Neurosurgery, Sestre milosrdnice University Hospital Centre, Zagreb, Croatia; \\ ${ }^{9}$ University of Applied Health Sciences
}

SUMMARY - Missile injuries are among the most devastating injuries in general traumatology. Traumatic brachial plexus injuries are the most difficult injuries in peripheral nerve surgery, and most complicated to be surgically treated. Nevertheless, missile wounding is the second most common mechanism of brachial plexus injury. The aim was to evaluate functional recovery after surgical treatment of these injuries. Our series included 68 patients with 202 nerve lesions treated with 207 surgical procedures. Decision on the treatment modality (exploration, neurolysis, graft repair, or combination) was made upon intraoperative finding. Results were analyzed in 60 (88.2\%) patients with $173(85.6 \%)$ nerve lesions followed-up for two years. Functional recovery was evaluated according to functional priorities. Satisfactory functional recovery was achieved in $90.4 \%$ of cases with neurolysis and $85.7 \%$ of cases with nerve grafting. Insufficient functional recovery was verified in ulnar and radial nerve lesions after neurolysis, and in median and radial nerve lesions when graft repair was done. We conclude that the best time for surgery is between two and four months after injury, except for the gunshot wound associated with injury to the surrounding structures, which requires immediate surgical treatment. The results of neurolysis and nerve grafting were similar.

Key words: Bracbial plexus; Neurosurgical procedures; Nerve block; Traumatology; Recovery of function

\section{Introduction}

Missile wounding of the brachial plexus is the second most common cause of the brachial plexus injuries (BPI) in peacetime, and the main, or even the only cause in previously published wartime series ${ }^{1-9}$. BPI may be caused by low or high velocity missiles, the for-

Correspondence to: Prof. Lukas Rasulić, MD, PhD, Department of Peripheral Nerve Surgery, Functional Neurosurgery and Pain Management Surgery, Clinic for Neurosurgery, Clinical Center of Serbia, Višegradska 26, 11000 Belgrade, Serbia

E-mail: lukas.rasulic@gmail.com

Received June 18, 2018, accepted August 16, 2018 mer being characterized by projectile velocity lower than $700 \mathrm{~m} / \mathrm{s}$ (hand guns, revolvers and shell fragments $)^{10}$. Nerve elements are damaged by small shock waves, temporary cavitations, and sometimes, by direct impact. Unless the nerve is transected by direct impact, spontaneous recovery can take place in the majority of cases, even in those patients with severe neurologic deficit at presentation ${ }^{2,11-15}$. These lesions are related to older military series ${ }^{16,17}$, and civilian practice ${ }^{2}$. Contrary to this, high-velocity missiles (over $700 \mathrm{~m} / \mathrm{s}$, averaging $1000 \mathrm{~m} / \mathrm{s}$ ) produced by modern rifles, machine guns, etc. cause more extensive damage. The destructive effect depends on the energy released, which is 
determined by mass, velocity, tumble and angle of incidence of a bullet ${ }^{18}$. Nerve elements are rarely injured by direct impact, nevertheless, shock waves and cavitation cause extensive damage through compression and stretching ${ }^{15,18,19}$, also involving soft tissues, blood vessels and bones. Spontaneous recovery may sometimes occur, when the nerve elements are only partially injured.

Many of the contemporary series are evaluating functional recovery of patients operated for BPI, regardless of the cause of the injury, mainly due to rarity of these injuries ${ }^{20-22}$. Missile injuries of the brachial plexus occur almost inextricably with war, while also carrying along specific associated injuries, and difficulties in diagnosing the injury and estimating the extension and level of severity.

The aim of this study was to present functional recovery of patients operated on after missile caused BPI, as well as to describe the surgical decision-making process.

\section{Patients and Methods}

This was a retrospective study including patients operated for missile caused BPI during the 24-year period between November 1991 and July 2015. All patients included in the study were operated at the Department of Peripheral Nerve Surgery, Functional Neurosurgery and Pain Management Surgery, Clinic for Neurosurgery, Clinical Center of Serbia in Belgrade, Serbia, the major referral center for traumatic peripheral nerve injury (PNI) treatment in Serbia.

\section{Patient selection}

Sixty-eight patients gave their consent to participate in the study and allowed us to publish data on their functional recovery. Follow up in the study was 2 years; during that period, eight (11.8\%) patients dropped out and data were analyzed for the remaining $60(88.2 \%)$ patients operated on. Eight patients were excluded from the study and further data analysis due to the missed medical examinations and functional outcome testing. Finally, 173 (85.6\%) of 202 operated nerve structures in 68 patients were analyzed. In the 60 patients analyzed, there were 75 neurolyzed elements, 44 grafted elements, and 8 with combined surgical procedures (e.g., neurolysis of the $\mathrm{C} 5$ and grafting of the C6 spinal nerve).

\section{Functional outcome testing}

Testing of functional outcome in the operated $\mathrm{pa}^{-}$ tients included motor and sensory function of the hand. Evaluation of motor recovery was performed according to the Medical Research Council Grading System for Nerve Recovery, with six grades, from M0 to $\mathrm{M} 5{ }^{23}$. Recovery of sensory function was, according to the same system, classified in five grades, from $\mathrm{S} 0$ to S4 (anesthesia, dysesthesia, protective sensation, and two point discrimination above and below $10 \mathrm{~mm})^{23,24}$.

Nerve functions that are of primary importance for daily activities and quality of life were tested. Nerve functions of marginal importance for quality of life, such as sensory function of the axillary nerve, were not evaluated (Table 1).

Table 1. Tested nerves and their functions

\begin{tabular}{|l|l|}
\hline Nerve & Function \\
\hline Median nerve & Motor and sensory \\
Ulnar nerve & Motor and sensory \\
Radial nerve & Motor \\
Musculocutaneous nerve & Motor \\
Axillary nerve & Motor \\
\hline
\end{tabular}

Within the evaluation of motor recovery of the median, ulnar and radial nerves, we considered function of the proximal and distal muscles separately. Results were classified in three groups. Good and fair results were estimated as useful functional recovery (Fig. 1) ${ }^{18}$.

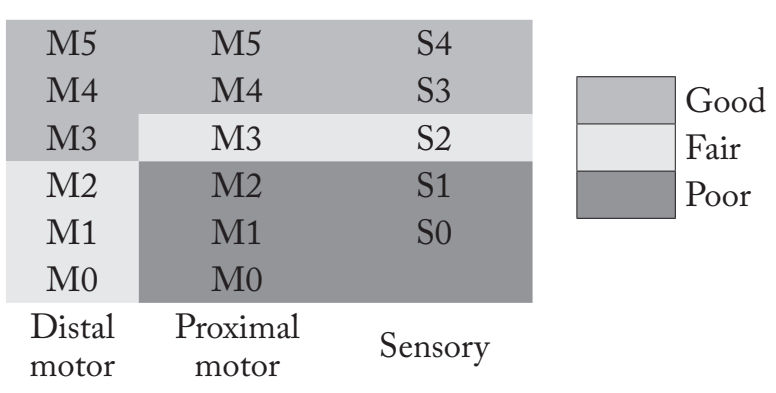

Fig. 1. Good, fair, and poor functional recovery, with good and fair being useful functional recovery.

Recovery following surgery of the lesions involving complex brachial plexus elements (spinal nerve to/or trunk and divisions to/or cord) was analyzed according to the functional priorities in brachial plexus surgery 
that included elbow flexion, shoulder abduction, wrist and finger flexion, protective sensation in the median nerve autonomous zone, and wrist and finger extension.

Functional recovery following surgery of upper brachial plexus elements (C5 and C6 spinal nerves to/ or upper trunk and $\mathrm{C} 5, \mathrm{C} 6$ and $\mathrm{C} 7$ spinal nerves to/or upper and middle trunk) was estimated as useful if both arm abduction innervated either by the axillary or suprascapular nerve, or both, and elbow flexion were in range M3 or more. Recovery of the wrist and finger flexion and extension was of less importance. The lower limits of M4 for elbow flexion and arm abduction in musculocutaneous and axillary nerve, M3 for wrist flexion and wrist and finger extension in median and radial nerve, and S3 in the median nerve autonomous zone were classified as good recovery, whereas M3 for elbow flexion and arm abduction in musculocutaneous and axillary nerve and $\mathrm{S} 2$ in the median nerve autonomous zone were classified as fair recovery.

Functional recovery following surgery of the lower brachial plexus elements (C8 and T1 spinal nerves to/ or lower trunk) was estimated as useful if finger flexion was at range M3 or more and there was at least protective sensation in the ulnar nerve autonomous zone. Good results in these cases included lower limits M4 for finger flexion, M3 for intrinsic hand muscles and S3 for sensory function. The results of surgery at the cord level were analyzed according to their outflows, taking into consideration functional priorities in brachial plexus surgery ${ }^{18}$.

Other data obtained from medical records of $\mathrm{pa}^{-}$ tients, relevant for this study were age and gender; rank, service, mechanism, type, location and severity of injury; surgical procedures; possible complications (i.e. any secondary problem that arose following an injury, procedure, or treatment); and disposition.

\section{Results}

The patients analyzed were aged 16 to 52 years and most of them (85\%) were younger than 40 years. Initial complete brachial plexus palsy was found in 40 (58.8\%), upper palsy in five (7.3\%) patients, lower palsy in one (1.4\%) patient, and $22(32.4 \%)$ patients had partial functional loss with combined lesion at the same or different levels. Partial spontaneous recovery after initial total brachial plexus palsy was recorded in $11(16.2 \%)$ patients 3 months after injury.
All surgeries were performed within 3 weeks to 12 months from injuries, 3 months on average. Fifty-one (75.0\%) of 68 patients were operated on within less than 6 months; 22 (32.3\%) patients had associated vascular injuries that required an emergency surgical intervention where nerve lesion was established and enabled earlier surgical treatment of the nerve elements.

In this study, there were $13(19.1 \%)$ patients with supraclavicular lesions and 55 (80.9\%) with infraclavicular or retro- and infraclavicular lesions. During the preoperative clinical examination, electromyography and somatosensory evoked potentials, we found injuries to 202 nerve elements of the brachial plexus, i.e. 207 nerve lesions verified intraoperatively. As seen in Table 2, 156 (77.2\%) of 202 injuries were located at terminal branches at their first several centimeters. There were two groups of 23 (11.4\%) brachial plexus elements, i.e. one damaged at the spinal nerve to the trunk level and another one damaged at division to the cord level.

\section{Table 2. Location of injury}

\begin{tabular}{|l|l|}
\hline Injured element & Number \\
\hline Spinal nerve to trunk or trunk & 23 \\
C5-C6 to upper trunk or upper trunk & 10 \\
C5-C7 to upper and middle trunk & 10 \\
or upper and middle trunk & \\
C8 to T1 to lower trunk or lower trunk & 3 \\
Divisions to cord or cord & 23 \\
Lateral cord & 9 \\
Medial cord & 9 \\
Posterior cord & 5 \\
Cord to nerve or nerve & 156 \\
Lateral to musculocutaneous & 25 \\
Lateral to median & 30 \\
Medial to median & 18 \\
Medial to ulnar & 19 \\
Posterior to axillary & 22 \\
Posterior to radial & 42 \\
\hline Total & 202 \\
\hline
\end{tabular}

Intraoperatively, the continuity of the nerves was found to be preserved (at least partially) in the majority of cases -157 (75.8\%) of 207 nerve elements: 34 (16.4\%) elements were macroscopically normal but compressed with external scarring, 103 (49.7\%) had 
Table 3. Type of lesion found intraoperatively

\begin{tabular}{|l|l|}
\hline Intraoperative finding & Number \\
\hline Complete loss of continuity & 50 \\
Partial loss of continuity & 20 \\
Neuroma in continuity or fibrosis & 103 \\
External scarring without nerve injury & 34 \\
\hline Total & 207 \\
\hline
\end{tabular}

Table 4. Surgical treatment performed on particular nerve structures

\begin{tabular}{|l|l|}
\hline Surgical treatment & Number \\
\hline Nerve grafting & $47^{\mathrm{a}}$ \\
Split repair & 20 \\
Interfascicular neurolysis & 77 \\
External neurolysis and exploration & $58^{\mathrm{b}}$ \\
Nerve transfer & $5^{\mathrm{c}}$ \\
\hline Total & 207 \\
\hline
\end{tabular}

ancluding ten extensive grafting procedures (spinal nerves to cords and spinal nerves or trunks to nerves); bincluding 34 elements with external scarring and nine neuromas in continuity on lower plexus elements that were not repaired; 'nerve transfers on the musculocutaneous and axillary nerves in two cases of C5-6 injury.

neuroma in continuity and/or epineurial fibrosis, and $20(9.66 \%)$ had partial loss of continuity. There were only 50 (24.1\%) of 207 nerve elements with complete loss of continuity (Table 3 ).

Surgical procedures are presented in Table 4. In most cases, neurolysis was performed (external and interfascicular neurolysis), i.e. 133 (64.2\%), followed by nerve graft in 47 (22.7\%), split repair in 20 (9.6\%), and nerve transfer in $5(2.4 \%)$ cases.

In two cases with $\mathrm{C} 5$ and $\mathrm{C} 6$, and in one case of $\mathrm{C} 7$ root injury, when direct graft repair was not possible, nerve transfers were performed to the musculocutaneous and axillary nerves.

In our study, there were 50 of 207 (24.1\%) nerve elements with complete functional loss, $16.5 \%$ were compressed by external scar, and $49.8 \%$ had lesions in continuity, and there was partial functional loss in $9.7 \%$ of nerve elements.

Useful functional recovery occurred in $89.7 \%$ (87 of 97) of cases with neurolysis and $90.0 \%$ (45 of 50) with nerve grafting. The rate of excellent recovery results was higher in neurolysis cases, 71 of 87 (81.6\%) vs. 28 of 45 (62.2\%) with graft repair (Table 5).
Table 5. Grade of recovery according to surgical treatment

\begin{tabular}{|l|l|l|l|}
\hline Surgical treatment & M5, M4 & M3 & M2, M1, M0 \\
\hline Nerve grafting & 28 & 17 & 5 \\
Neurolysis & 71 & 16 & 10 \\
Combination $^{\mathrm{a}}$ & 8 & 2 & 2 \\
\hline Total & 107 & 35 & 17 \\
\hline
\end{tabular}

${ }^{a}$ Combination of neurolysis and nerve grafting

Useful functional recovery after neurolysis for divisions to cord level was seen in all ten elements, for terminal branches with useful functional recovery for 82 (91.1\%) of 90 elements.

Nerve grafting of proximal brachial plexus lesions resulted in 100\% useful functional recovery; for terminal branches, there were 37 (86.0\%) of 43 nerves.

Finally, a combination of these procedures (nerve grafting and neurolysis) had useful functional recovery in all six lesions (Table 6).

Comparing both procedures performed for musculocutaneous and axillary nerves, there was only one case of poor recovery; that patient had already had hypotrophy and contracture of hand muscles. The rate of good results was $90 \%$ for the musculocutaneous nerve in neurolyzed and grafted cases; for axillary nerve, it was $94.4 \%$ for neurolysis and $75 \%$ for nerve grafting.

Poor recovery was verified for the ulnar and radial nerve lesions in neurolyzed cases, and in median and radial nerve lesions in cases with graft repair.

Our study results indicated that neurolysis yielded $90.4 \%$ of functional recovery ( $75 \%$ had excellent functional recovery) versus $85.7 \%$ for nerve grafting $(62.5 \%$ with excellent recovery). Upper elements of brachial plexus showed functional recovery after neurolysis, comparing the lateral and posterior cord (100\%) and medial cord (75\%).

Functional recovery after neurolysis of terminal branches of the brachial plexus was as follows: axillary nerve $100 \%$, musculocutaneous nerve $100 \%$, medial median and lateral median 100\%, radial nerve $84 \%$ and ulnar $69.2 \%$.

Comparing the grade of recovery of nerve structures and surgical procedure, there was statistical significance for neurolysis $(p=0.008, p<0.05)$. There was no statistical significance for nerve grafting $(\mathrm{p}=0.131$, $\mathrm{p}>0.05)$. 
Table 6. Grade of recovery of operated nerve structures of brachial plexus

\begin{tabular}{|c|c|c|c|c|c|c|c|c|}
\hline \multirow{2}{*}{ Nerve structure } & \multicolumn{3}{|c|}{ Neurolysis } & \multicolumn{3}{|c|}{ Nerve grafting } & \multicolumn{2}{|c|}{ Combination } \\
\hline & M5M4 & M3 & M2M1M0 & M5M4 & M3 & M2M1M0 & M5M4 & M3 \\
\hline \multicolumn{9}{|l|}{ Spinal nerve to trunk or trunk } \\
\hline $\begin{array}{l}\text { C5-C6 to upper trunk or upper } \\
\text { trunk }\end{array}$ & & & \multirow[b]{3}{*}{1} & 2 & \multirow{3}{*}{3} & \multirow[b]{3}{*}{1} & \multirow[t]{3}{*}{2} & \multirow{3}{*}{1} \\
\hline $\begin{array}{l}\mathrm{C} 5-\mathrm{C} 7 \text { to upper and middle trunk } \\
\text { or upper and middle trunk }\end{array}$ & & & & 2 & & & & \\
\hline $\begin{array}{l}\mathrm{C} 8 \text { to } \mathrm{T} 1 \text { to lower trunk or lower } \\
\text { trunk }\end{array}$ & & & & & & & & \\
\hline \multicolumn{9}{|l|}{ Divisions to cord or cord } \\
\hline Lateral cord & 6 & & \multirow{3}{*}{1} & 2 & & 1 & & \\
\hline Medial cord & 2 & 1 & & & & & & \\
\hline Posterior cord & 2 & 1 & & 2 & & & & \\
\hline \multicolumn{9}{|l|}{ Cord to nerve or nerve } \\
\hline Musculocutaneous & 13 & & \multirow{6}{*}{4} & 9 & & 1 & & \\
\hline Median (lateral) & 12 & 3 & & 8 & 4 & 1 & & \\
\hline Median (medial) & 4 & 2 & & 1 & 4 & 2 & & \\
\hline Ulnar & 7 & 2 & & 1 & & & & \\
\hline Axillary & 17 & 1 & & 3 & 1 & & & \\
\hline Radial & 15 & 6 & & 4 & 2 & 2 & & \\
\hline Total & 78 & 16 & 10 & 34 & 14 & 8 & 4 & 2 \\
\hline
\end{tabular}

\section{Discussion}

Mortality caused by missile injuries of the upper extremities is relatively lower in relation to mortality after missile injury to the head, chest or abdomen, as reported by Dougherty et al. According to these authors, more than $65 \%$ of the wounded survivors had an extremity injury ${ }^{8}$.

In this article, we present experience with 60 gunshot injuries to the brachial plexus operated on during the war in former Yugoslavia and the period thereafter.

Missile injuries are considered to be an etiologic origin of brachial plexus injuries in about $25 \%$ of cases. There are not many large series on this subject published in the literature. Brooks in 1954, and Nulsen and Slade in 1956 published the British and American experiences from the World War II with 170 and 117 open wounds to the brachial plexus, respectively ${ }^{16,17}$. Another large series was reported by Kline and Judice in $1983^{11}$, and Kline in $1989^{2}$, which analyzed injuries in a series of 141 civilians where 90 of them were operated on, and 75 followed up for over two years. In recent military conflicts, these injuries accounted for
$2.6 \%$ to $14 \%$ of all peripheral nerve injuries ${ }^{25-27}$. Also, there have been only a few large series of missile brachial plexus injuries in civilian practice published recently ${ }^{12-14}$. Comparative analysis of these studies is not possible, not only due to different wounding circumstances, but particularly because of the diagnostic and therapeutic improvements in peripheral nerve surgery during the lengthy period ${ }^{18}$.

\section{Clinical characteristics}

Earlier reports emphasized the partial neurologic deficit in a large number of cases, with the possibility of spontaneous recovery, especially in upper trunk and posterior cord but not in injuries of lower elements ${ }^{16,17}$. Since the first published series, when Brooks reviewed only 54 patients operated on within 170 open injuries $^{16}$, Nulsen and Slade have reported a larger number of operated patients $(76 \%)^{17}$. Kline and Kline and Judice have also reported a similar operation rate in their series $(63.8 \%)^{2,11}$. Although complete functional loss in distribution of all nerve elements at the injured level was present in only 19 (21\%) patients, Kline stated 
that complete injury to one element could recover spontaneously (but often will not) while incomplete functional loss in distribution of one element usually recovered spontaneously, but did not guarantee recovery of other elements ${ }^{2,18}$.

In recent years, it has been appreciated that many missile injuries to the brachial plexus do not recover spontaneously but they cause persistent pain and severe disability although lesions in continuity are com$\operatorname{mon}^{19,25,28}$. The majority of these lesions have complete functional loss ${ }^{12,15}$. Kim et al. found complete loss in $69 \%$ of the nerve elements, which is quite contradictory to earlier reports ${ }^{12}$. Moreover, among $62.9 \%$ of cases with spontaneous recovery, Samardzic et al. ${ }^{18}$ recorded complete functional loss in distribution of all brachial elements in only $16.6 \%$ of them. A significant number of patients with injury of the upper trunk and posterior cord, presenting with partial neurologic deficit, may recover spontaneously but not those with injury to the lower elements ${ }^{15}$. The patients showing the signs of spontaneous recovery during the first four weeks are likely to have good or excellent outcome ${ }^{28}$. There was no complete spontaneous recovery or recovery of complete loss in distribution of one nerve element ${ }^{15}$. It should be emphasized that lesions in continuity, with functionally and electromyographically complete loss at three months post injury showed transmission of nerve impulses in $23 \%$ of elements, indicating neurolysis as the method of choice ${ }^{29}$. Lesions at the multiple levels of the brachial plexus are common and they will never recover spontaneously ${ }^{19}$.

\section{Characteristics of nerve lesions}

According to the previously published series ${ }^{12,13,16,17}$, a large majority of lesions preserved some nerve continuity. Brooks found division of some neural elements in $29.6 \%$ of operated patients ${ }^{16}$. Kline found $46.6 \%$ of nerve elements with complete functional loss without any continuity ${ }^{11}$. Lesions in continuity were found in 221 elements, and $75 \%$ of them had complete functional loss. Among nerve elements with incomplete loss, only seven required nerve repair. On the contrary, in the first group, intraoperative nerve action potential studies confirmed signs of early regeneration in 48 (28.9\%) of these elements and only neurolysis or split repair had to be performed.

Samardzic et al. ${ }^{18}$ report on the $23.9 \%$ incidence of nerve elements without any continuity and conse- quently with complete functional loss. Among the remaining nerve elements, $15.3 \%$ were preserved but compressed by external scar, and $60.8 \%$ had lesions in continuity (fibrosis, neuroma in continuity, or partial loss of continuity). Recent series confirmed predomination of nerve lesions in continuity ${ }^{13,15,25,28,29}$.

Gunshot wounds to this region may also injure the neighboring vessels (axillary and subclavian arteries and veins), bones (clavicle, scapula, humerus and ribs) and viscerals (lung, pharynx, esophagus, etc. $)^{19}$. Generally, there is a high incidence of associated injuries. The most frequent are vascular injuries, over $30 \%{ }^{28}$, that present as two types. The first is major vascular interruption and the second presents as a pseudoaneurysm, which is often difficult to diagnose and treat ${ }^{14}$. Bone fractures increase the risk of nerve damage since the shattered bone fragments become secondary projectiles and travel in almost all directions causing extra damage to surrounding tissues ${ }^{15,19}$.

\section{Indications and timing of surgery}

Nulsen and Slade stated that the best results were obtained with early exploration and repair ${ }^{17}$. However, if the lesion in continuity was found upon exploration, resection was delayed for 3 to 6 months to allow for possible spontaneous recovery; in the absence of spontaneous recovery during that period, resection of the lesion was indicated ${ }^{17}$. Similarly, Kline and Tiel indicated surgery if, upon clinical examination, there was complete loss in distribution of one or more nerve elements persisting for at least 4 months ${ }^{29}$.

Clean wound without infection, a stable bone fracture and skin closure over neurovascular structures are important reasons for delaying surgery ${ }^{15}$. Another reasons concerning nerve elements are difficult evaluation of nerve damage, and possibility of spontaneous recovery $^{18,30}$. Generally, operation is indicated if at the time of clinical examination there is no recovery, or if there is non-anatomic recovery in distal but not in proximal muscles, or other, if there is complete functional loss in distribution of one or more nerve elements persisting for at least 3 months, a period allowing for spontaneous recovery of the first three grades of injury ${ }^{14,17,28}$. Association with vascular injuries may warrant emergency surgery. However, the question arises whether the brachial plexus repair should be performed or not. In most instances, it is much better to leave nerve injury for secondary repair ${ }^{19,31}$. Early exploration and 
nerve repair during the first 3 months are indicated in cases with progressive neurologic deficit because of an aneurysm or arteriovenous fistula, or in cases with non-causalgic pain resistant to conservative treatment, especially if foreign or bone fragments are present in the brachial plexus ${ }^{11}$. If loss of nerve continuity was documented upon early exploration, early secondary repair was indicated ${ }^{19}$. It should be mentioned that in these cases and in cases with fibrotic or unavailable proximal nerve stump for grafting, there is a possibility for performing some of nerve transfers ${ }^{19,29}$.

Delayed surgery for up to 6 months is not prognostically unfavorable. In this period, operation is indicated if there is a stop or failure in anatomic recovery, if there is dissociated recovery with a difference between motor and sensory functional improvement, or if there is uneven functional recovery with regular chronology but absence of improvement in some muscles $^{18}$. Downgrading of the operative results is proved if surgery is delayed for more than 1 year, and this could be the reason for nonoperative treatment ${ }^{2,11,30,32}$.

Adult patients with lesions of the $\mathrm{C} 8$ and $\mathrm{T} 1$ spinal nerves, lower trunk, medial cord and its outflows are suited for conservative treatment unless pain is resistant to medication ${ }^{30}$.

\section{Outcome and prognosis}

On the basis of the results obtained, Brooks concluded that surgery of gunshot wounds to the brachial plexus was "rarely profitable and justifiable" because recovery occurred only after upper trunk or $\mathrm{C} 5$ and $\mathrm{C} 6$ spinal nerve suture ${ }^{16}$. Neurolysis of other elements did help with pain relief but rarely improved functional outcome. Nulsen and Slade made similar observations. The recovery occurred after suture of the upper spinal nerves and trunk, and in the proximal muscles after repair of the lateral and posterior cord. Surgical repair of the lower elements and grafting procedures were not successful ${ }^{17}$. Kline ${ }^{2}$ obtained useful functional recovery in $92 \%$ of neurolyzed cases. The rate of recovery for elements thought to be prognostically favorable was 96\%; for the prognostically unfavorable ones it was 79\%. Direct suture gave a total rate of recovery of $69 \%$, while nerve grafting gave a rate of $54 \%$.

Results of nerve repair were especially favorable for the upper spinal nerves, upper trunk, and the lateral and posterior cords and their nerves, with a total rate of recovery of $83 \%$ for direct suture and $66 \%$ for nerve grafting, ranging from $50 \%$ to $100 \%$ according to different nerve segments. Repair of the $\mathrm{C} 7$ spinal nerve and middle trunk gave a rate of recovery of $45 \%$ for grafting procedures. As far as the lower spinal nerves, lower trunk and medial cord are concerned, only the medial cord to median nerve repair gave useful recovery in $66.6 \%$ of cases with direct suture and in $53 \%$ of nerve grafting cases. On the basis of these results, Kline concluded that nerve repair of the brachial plexus injuries caused by gunshot wounds was not only possible but actually produced acceptable results ${ }^{2}$. Furthermore, he concluded that end-to-end repair was usually but not always possible. More recent reports confirmed his findings. Rates of recovery obtained by neurolysis ranged from $90 \%$ to $94 \%^{7,18,25}$. The failures were mostly related to lesions of the lower trunk, ulnar and radial nerves ${ }^{32}$. The results were especially good if the nerve element was compressed by scar or it was in continuity with neuroma of fibrosis ${ }^{30}$. Approximately $70 \%$ of the lesions repaired by direct suture had successful functional recovery ${ }^{13}$, with one exception. Secer et al. obtained functional recovery in only $36.6 \%$ of direct sutures and in $56.5 \%$ of partial direct sutures ${ }^{30}$. Nerve grafting was performed in lesions with loss of continuity, total or partial, and in lesions in continuity without transmission of nerve action potentials ${ }^{2,11}$. The techniques used were interfascicular nerve grafting in split-nerve repairs, and this technique or modified cable nerve grafting in complete nerve transections ${ }^{19}$. The reported rates of recovery ranged from $70 \%$ to $89 \%$ of cases ${ }^{7,18,19,25}$, although Secer et al. report a total rate of recovery of only $16.6 \%{ }^{30}$. Some of the factors influencing favorable results are the use of short nerve grafts $^{18}$, a significant number of split-nerve repairs ${ }^{2,15}$, and surgery performed during the first three months. However, the most important factor is nerve grafting on elements thought to be prognostically favorable such as the C5, C6 and possibly C7 spinal nerves, upper trunk, lateral and posterior cords, and musculocutaneous and axillary nerves $7,18,19,25,30$. This is especially true for the infraclavicular lesions involving the lateral cord and musculocutaneous nerve because the target muscles are relatively closer than in other situations ${ }^{31}$.

Neurolysis and repair of the lower nerve elements including the $\mathrm{C} 8$ and $\mathrm{T} 1$ spinal nerves, lower trunk, medial cord and ulnar nerve, exceptionally may give functional improvement ${ }^{18,25,30}$, but helped only with pain relief ${ }^{30}$. However, Siqueira et al. obtained reinner- 
vation of the wrist and digital flexors in $50 \%$ to $60 \%$ of cases without reinnervation of the intrinsic muscles ${ }^{31}$. Sensory reinnervation in the median nerve area was achieved in $70 \%$ to $80 \%$ of cases ${ }^{16,31}$. Non-causalgic pain may be related to partial transections, especially in the lower elements, or their compression by scar. This pain responds well to external and internal neurolysis $^{19,27,33}$.

It should be emphasized that final outcome is greatly influenced by the existence of associated injuries (vascular lesions, bone fractures, and soft tissue defects) ${ }^{13,15}$. Vascular lesions affect nerve elements through ischemia. Bone fragments may cause additional nerve damage or subsequent callus spread around the repaired nerve ${ }^{30}$. Finally, skin and muscle defects are reasons for significant delay of nerve repair.

The failures were verified for the ulnar and radial nerve lesions in neurolyzed cases and in grafted cases for the lateral and medial part of the median and radial nerve lesions, and in one case for the musculocutaneous lesions (our patient already had hypotrophy and contractures of muscles).

We have to emphasize that we did not find any differences between war and civilian missile injuries regarding the level of injury, affected nerve elements, type of injury, surgical procedure performed and outcome.

\section{Conclusion}

In this study, we found a higher incidence of total brachial plexus palsy (58.8\%), while partial spontaneous recovery at initial brachial plexus palsy was rare (16.2\% of patients). Neurolysis and nerve grafting produced similar results of functional recovery in regard to the level and type of lesion.

According to the reported experiences ${ }^{2,7,13,15,16,18,19,25,30,31}$, we were able to make several conclusions, as follows:

- in a significant number of cases, gunshot wounds to the brachial plexus produce lesions in continuity with incomplete functional loss which may recover spontaneously, or complete loss which usually do not;

- associated vascular injury is the reason for emergency surgical exploration;

- the possibility of spontaneous recovery and difficult initial evaluation of nerve lesions are the reasons for delayed surgery and nerve repair, two to four months after injury;
- after this period, surgery is indicated if there is complete loss in distribution of one or more nerve elements, if there is incomplete loss that does not improve spontaneously, or if there is pseudoaneurysm or fistula compressing nerve elements;

- surgery delayed for more than one year is not justifiable;

- neurolysis in lesions with preserved nerve continuity gives useful functional recovery in over $90 \%$ of cases;

- similar results may be obtained by nerve grafting on elements thought to be prognostically favorable such as C5 and C6 spinal nerves, upper trunk, lateral and posterior cord and their outflows; and

- the lesions of lower brachial plexus elements are subject of conservative treatment except for cases with resistant non-causalgic pain.

\section{References}

1. Faglioni W, Jr., Siqueira MG, Martins RS, Heise CO, Foroni L. The epidemiology of adult traumatic brachial plexus lesions in a large metropolis. Acta Neurochir (Wien). 2014;156(5): 1025-8. 10.1007/s00701-013-1948-x

2. Kline DG. Civilian gunshot wounds to the brachial plexus. J Neurosurg. 1989;70(2):166-74. 10.3171/jns.1989.70.2.0166

3. Vrebalov-Cindro V, Reic P, Ognjenovic M, Jankovic S, Andelinovic S, Karelovic D, et al. Peripheral nerve war injuries. Mil Med. 1999;164(5):351-2.

4. Rasulic L, Savic A, Lepic M, Puzovic V, Karaleic S, Kovacevic V, et al. Epidemiological characteristics of surgically treated civilian traumatic brachial plexus injuries in Serbia. Acta Neurochir (Wien). 2018;160(9):1837-45. 10.1007/s00701-018-3640-7

5. Jain DKA, Bhardwaj P, Venkataramani H, Sabapathy SR. An epidemiological study of traumatic brachial plexus injury patients treated at an Indian centre. Indian J Plastic Surg. 2012;45(3):498-503.

6. Kim DH, Murovic JA, Tiel RL, Kline DG. Mechanisms of injury in operative brachial plexus lesions. Neurosurg Focus. 2004;16(5):E2.

7. Samadian M, Rezaee O, Haddadian K, Sharifi G, Abtahi H, Hamidian M, et al. Gunshot injuries to the brachial plexus during wartime. Br J Neurosurg. 2009;23(2):165-9. 10.1080/02688690902756686

8. Dougherty AL, Mohrle CR, Galarneau MR, Woodruff SI, Dye JL, Quinn KH. Battlefield extremity injuries in Operation Iraqi Freedom. Injury. 2009;40(7):772-7. 10.1016/j.injury.2009.02.014 
9. Razaq S, Yasmeen R, Butt AW, Akhtar N, Mansoor SN. The pattern of peripheral nerve injuries among Pakistani soldiers in the war against terror. J Coll Physicians Surg Pak. 2015;25 (5):363-6.

10. Bowyer GW. Management of small fragment wounds in modern warfare: a return to Hunterian principles? Ann R Coll Surg Engl. 1997;79(3):175-82.

11. Kline DG, Judice DJ. Operative management of selected brachial plexus lesions. J Neurosurg. 1983;58(5):631-49. 10.3171/ jns.1983.58.5.0631

12. Kim DH, Cho Y-J, Tiel RL, Kline DG. Outcomes of surgery in 1019 brachial plexus lesions treated at Louisiana State University Health Sciences Center. J Neurosurg. 2003;98(5): 1005-16.

13. Kim DH, Murovic JA, Tiel RL, Kline DG. Penetrating injuries due to gunshot wounds involving the brachial plexus. Neurosurg Focus. 2004;16(5):1-6.

14. Kim DH, Murovic JA, Tiel RL, Kline DG. Gunshot wounds involving the brachial plexus: surgical techniques and outcomes. J Reconstr Microsurg. 2006;22(2):67-72. $10.1055 / \mathrm{s}-2006-932499$

15. Secer HI, Daneyemez M, Tehli O, Gonul E, Izci Y. The clinical, electrophysiologic, and surgical characteristics of peripheral nerve injuries caused by gunshot wounds in adults: a 40 -year experience. Surg Neurol. 2008;69(2):143-52; discussion 152. 10.1016/j.surneu.2007.01.032

16. Brooks DM. Open wounds of the brachial plexus. Spec Rep Ser Med Res Counc (G B). 1954;282:418-29.

17. Nulsen FE, Slade WW. Recovery following injury to the brachial plexus. In: Woodhal BG, ed. Peripheral Nerve Regeneration: A Follow-Up Study of 3656 World War II Injuries. Washington, DC: Government Printing Office; 1956:389-408.

18. Samardzic MM, Rasulic LG, Grujicic DM. Gunshot injuries to the brachial plexus. J Trauma. 1997;43(4):645-9.

19. Bhandari P, Sadhotra L, Bhargava P, Bath A, Mukherjee M, Singh $\mathrm{P}$, et al. Management of missile injuries of the brachial plexus. Indian J Neurotrauma. 2006;3(01):49-54.

20. Arzillo S, Gishen K, Askari M. Brachial plexus injury: treatment options and outcomes. J Craniofac Surg. 2014;25(4): 1200-6. 10.1097/SCS.0000000000000841

21. Gao KM, Hu JJ, Lao J, Zhao X. Evaluation of nerve transfer options for treating total brachial plexus avulsion injury: a ret- rospective study of 73 participants. Neural Regen Res. 2018; 13(3):470-6. 10.4103/1673-5374.228730

22. Limthongthang R, Bachoura A, Songcharoen P, Osterman AL. Adult brachial plexus injury: evaluation and management. Orthop Clin North Am. 2013;44(4):591-603. 10.1016/j.ocl.2013.06.011

23. Lee SK, Wolfe SW. Peripheral nerve injury and repair. J Am Acad Orthop Surg. 2000;8(4):243-52.

24. Millesi H. Treatment of nerve lesions by fascicular free nerve grafts. In: Mischon J, Moberg E, eds. Traumatic nerve lesions of upper limbs. Edinburgh, Scotland: Churchill Livingstone; 1975:91-100.

25. Stewart MP, Birch R. Penetrating missile injuries of the brachial plexus. J Bone Joint Surg Br. 2001;83(4):517-24.

26. Goushed J. The treatment of war injuries of the brachial plexus. J Hand Surg. 1995;20(3):S68-S76.

27. Roganovic Z, Mandic-Gajic G. Pain syndromes after missilecaused peripheral nerve lesions: Part 1. Clinical characteristics. Neurosurgery. 2006;59(6):1226-36; discussion 1236-7. 10.1227/01.NEU.0000245610.01732.32

28. Vrettos BC, Rochkind S, Boome RS. Low velocity gun shot wounds of the brachial plexus. J Hand Surg Br. 1995;20(2): 212-4.

29. Kline DG, Tiel RL. Direct plexus repair by grafts supplemented by nerve transfers. Hand Clin. 2005;21(1):55-69, vi. 10.1016/j.hcl.2004.09.002

30. Secer HI, Solmaz I, Anik I, Izci Y, Duz B, Daneyemez MK, et al. Surgical outcomes of the brachial plexus lesions caused by gunshot wounds in adults. J Brachial Plex Peripher Nerve Inj. 2009;4(1):11. 10.1186/1749-7221-4-11

31. Siqueira MG, Martins RS. Surgical treatment of adult traumatic brachial plexus injuries: an overview. Arq Neuropsiquiatr. 2011;69(3):528-35.

32. Grujicic D, Samardzic M. Open injuries of the brachial plexus. In: Samardzic M, Antunovic V, eds. Nerve Repair of Brachial Plexus Injuries. Rome, Italy: CIC Edizioni Internazionali; 1996:132-9.

33. Roganovic Z, Mandic-Gajic G. Pain syndromes after missilecaused peripheral nerve lesions: Part 2. Ttreatment. Neurosurgery. 2006;59(6):1238-49; discussion 1249-51. 10.1227/01. NEU.0000245618.16979.32 
Sažetak

\section{LIJEČENJE PROJEKTILNIH OZLJEDA BRAHIJALNOG PLEKSUSA}

\section{Rasulić, V. Simić, A. Savić, M. Lepić, V. Kovačević, V. Puzovic, F. Vitošević, N. Novaković, M. Samardžić i K. Rotim}

Ozljede projektilima su među najrazornijim ozljedama u općoj traumatologiji. Traumatske ozljede brahijalnog pleksusa najteže su ozljede perifernog živčanog sustava, a najkompliciranije se liječe kirurški. Ipak, projektilno ranjavanje je drugi najčešći mehanizam ozljede brahijalnog pleksusa. Cilj je bio procijeniti funkcionalni oporavak nakon kirurškog liječenja ovih ozljeda. Naša studija je obuhvatila 68 bolesnika s 202 ozljede živaca liječenih u 207 kirurških zahvata. Odluka o načinu liječenja (eksploracija, neuroliza, direktna reparacija graftom ili kombinacija) donesena je na osnovi intraoperacijskog nalaza. Rezultati su analizirani u 60 (88,2\%) bolesnika sa 173 (85,6\%) lezije živaca nakon kojih je slijedilo razdoblje praćenja u trajanju od dvije godine. Funkcionalni oporavak ocijenjen je prema funkcionalnim prioritetima. Zadovoljavajući funkcionalni oporavak postignut je u 90,4\% neuroliza i 85,7\% reparacija graftom. Slučajevi s nedovoljnim funkcionalnim oporavkom bili su povezani s neurolizom ulnarnog i radijalnog živca ili reparacijom graftom srednjih i proksimalnih lezija. Zaključujemo da je najbolje vrijeme za kirurški zahvat između dva i četiri mjeseca nakon ozljede, osim kada postoje udružene ozljede okolnih struktura, što zahtijeva neodložno kirurško liječenje. Rezultati neurolize i reparacije graftom bili su slični.

Ključne riječi: Brabijalni pleksus; Neurokirurški zabvati; Živčana blokada; Traumatologija; Oporavak funkcije 